\title{
HOW SHOULD SHARI'AH PRINCIPLES BE APPLIED IN MODERN COMPANY?
}

\author{
Burhanuddin Susamto \\ Fakultas Syari'ah UIN Maulana Malik Ibrahim Malang \\ Email: burhanuddins.uin@gmail.com
}

\begin{abstract}
Abstrak
The purpose of this study is to show why the modern business institution (company) should be Islamized, and to suggest ways in which shari'ah principles can be applied in the company. To achieve this purpose, we should understand how company be islamized in comprehensive and integrated manner through the Islamic law perspective, with the contemporary issues like underlying contract of company, legal entity, and the concept of liability. The resolution of these issues is important to assert that shari'ah principles could be applied in the modern company by integrating approach. An integrating approach in the treating of these issues has, however, been lacking, nor has it been subjected to a thorough legal analysis through the principles of Islamic business law.

Tujuan dari pembahasan ini adalah untuk menunjukkan bahwa institusi bisnis modern (perusahaan) harus diislamisasi, dan member masukan cara-cara bagimana prinsipprinsip shari'ah dapat ditetapkan dalam perusahaan. Untuk mencapai tujuan ini, kita perlu memahami bagaimana perusahaan diislamisasi secara menyeluruh dan terintegrasi melalui perspektif hukum Islam terhadap persoalan kontemporer, seperti landasan kontrak perusahaan, badan hukum, dan konsep liabilitas. Solusi dari persoalan ini sangat penting untuk menegaskan bahwa prinsip-prinsip shari'ah dapat ditetapkan pada perusahaan modern melalui pendekatan integrasi. Bagaimanapun, pendekatan integrasi dalam menyikapi persoalan ini jarang dilakukan, disamping tidak menjadi tema analisis melalui prinsip-prinsip hukum bisnis Islami.
\end{abstract}

Keyword: Company, Shari'ah Principles, Liability

In Indonesia, the term "perusahaan" (company) could not be separated from the word "usaha", namely every action, deed or any activity in the economy field, which is done by each entrepreneur for the purpose of obtaining profit. $^{1}$ The company is any form of entity running any kind of business consistently and continuously which is established, work and domicile in territory of

${ }^{1}$ See (Pasal 1 huruf d) Undang-Undang No.3 Tahun 1982 tentang Wajib Daftar Perusahaan. [Article 1 (d) Law No. 3 of 1982 concerning The Compulsory Enterprise Registration] the Republic of Indonesia, for the purpose of gaining advantage. ${ }^{2}$ While every person who runs his own company called entrepreneurs. ${ }^{3}$ Entrepreneurs are people who run the company or appoint other workers to run the company. If the entrepreneurs running a company involve the workers, they have two functions namely as the owner and at the

\footnotetext{
${ }^{2}$ Ibid., Article 1 (b)

${ }^{3}$ Abdulkadir Muhammad, Pengantar Hukum Perusahaan di Indonesia, (Bandung: Citra Aditia Abadi, 1995), hlm. 10
} 
same time as company director. ${ }^{4}$ Whereas if the entrepreneurs give management to workers as whole, they are just as the owners without leading company directly.

From a historical viewpoint, company law in Indonesia had elderly. During the colonial period, the Netherlands-Indies Government implemented the concordantie principle in the legal sector throughout the territory of Indonesia. On the basis of this principle, virtually every law that was passed by the Netherlands parliament would take effect in the Indonesian territory a few years later. When Indonesia became independent, its 1945 Constitution in Article II of the Transitory Provisions stipulated that all laws and legislation existing under the Dutch colonial administration automatically became the laws and legislation of the Republic of Indonesia, until amended or found to be contradictory to the Constitution. ${ }^{5}$ The first time, therefore, since 1848 there is a regulation of Indonesia company originated from The Netherlands and had been in effect in business law, Commercial Code (KUHD).

From the explanation above can be found that there is foreign product of rule applied in Indonesia to regulate the establishment of company. ${ }^{6}$ Some domestic products which are related to practices of companies in Indonesia are Act No. 40 of 2007 concerning Limited Liability Company and Act No. 3 of 1982 concerning Compulsory Enterprise Registration. ${ }^{7}$ In a view of figh, the application

\footnotetext{
${ }^{4}$ Ibid., p. 29

${ }^{5}$ Indonesia Constitution of 1945 in Article II of Transitory Provisions

${ }^{6}$ Article $16-35$ of Indonesia Commercial Code [KUHD], cet ke-4 (Bandung: Citra Umbara, 2010), p. 6-10

${ }^{7}$ Company registration law was applied to all companies both sole proprietorship and partnership. The fact, however, many sole proprietorships which are unregistered because of activating in the informal sectors. According to Chapter II Article 2 of Act No. 3 of 1982, state that the purpose of the company's registration is to record information materials loaded correctly from a company and is a source of official information for all interested parties concerning the identity, data and other information about companies listed on the list of companies in order to ensure business certainty. This provision in accordance with the spirit of al-Quran: "O you who believe! When you deal
}

of procedural rules (hukm al-ijrai) is permissible as long as not contrary to Islamic law (hukm al-syar'i). Has Indonesian company been in step with shari'ah principles, it is required further analysis.

A Muslim entrepreneur has to bind his activities to the shari'ah law when running the company. In the shari'ah law can be found the certain principles that can be applied to the scope of business organization/ company. For example in an environment of financial institutions, the shari'ah principles have been applied not only at the management level (moral value), but also include at the operational system itself. From its experience we hope that shari'ah principles can be applied in the company system engaged in the production sector of goods and services. ${ }^{8}$ The company that run business based on shari'ah principles could be called as Islamic company.

In the Islamic business law, terms "usaha" are often interpreted as an effort ${ }^{9}$ of human beings to obtain their livelihoods. ${ }^{10}$ Although human effort is a variety, ${ }^{11}$ the most important thing is to reach the pleasure of Allah. ${ }^{12}$ Related to the term effort, in the Quran has been explained that a man will get nothing than what has been earned. ${ }^{13}$ Therefore simple wisdom of quote the Quran verses is, if someone want to get an advantage, they must return to the shari'ah law. Is not the result of all effort that has been done in the world will be shown ${ }^{14}$ and in the hereafter will be asked to accountability? ${ }^{15}$ Further, how to apply shari'ah principles in

with each other, in transactions involving future obligations in a fixed period of time, let you write. And write down faithfully as between the parties..." (QS.Al-Baqarah[2]: 282).

${ }^{8}$ Burhanuddin S, Hukum Bisnis Syariah, cet ke-1, (Yogyakarta: UII Press, 2010), p. 17

${ }^{9}$ Spend (in Allah's way) some of the results of your best efforts (QS.Al-Bagarah[2]:267). Term the business in that paragraph relating to the activities make a living (maisyah), some of them through the business.

${ }^{10}$ (QS.Al-A'raaf[7]:10)

${ }^{11}$ (QS.Al-Lail [92]: 4)

${ }^{12}$ (QS. Ar-Rum[30]: 30)

${ }^{13}$ (QS.An-Najm [53]: 39).

${ }^{14}$ (QS.An-Najm [53]: 40)

${ }^{15}$ (QS.Al-Muddatsir [74]: 38) 
the establishment of modern company and its operations, is a crucial issue which has not been widely described.

Application of shari'ah principles in an Indonesian company has had a legal basis. According to Article 109 of the Limited Liability Law No. 40 of 2007 have stated that: (1) Apart from a Board of Commissioners, companies doing business based on shari'ah principles must have a Shari'ah Supervisory Board; (2) The Shari'ah Supervisory Boards contemplated in paragraph (1) shall consist of one or more shari'ah experts appointed by the GeneralMeeting ofShareholders/RUPSon the recommendation of the Indonesian Council of Ulema; (3) The Shari' ah Supervisory Boards contemplated in paragraph (1) shall have the task of giving advice and suggestions to the Board of Directors and supervise companies' activities so that they are in accordance with shari' ah principles.

The mention of the "shari'ah" term formally, both at the level of concept and implementation, is an important step to develop Islamic company. Otherwise, interpret shari'ah term limited to the values , ethics or morals alone, however, will has no the reconstruction power. ${ }^{16}$ The legality of institution having vital significance for society is questioned only when the principles violated are so basic to the system that permitting the institution to function may amount to giving up a major part of Islamic law. This is usually happens when the principles violated are to be found directly in the Qur'an and Sunnah, both of which are the primary sources of Islamic law. ${ }^{17}$

A company is essentially a contract where people come together and instead of paying themselves a salary they distribute the profits amongst themselves. In origin a company is a contractual matter and Islam has laid out detailed rules for contracts. In Islamic contracts there must be an offer and

${ }^{16}$ Burhanuddin S., Pasar Modal Syariah: Tinjauan Hukum, (Yogyakarta: UII Press, 2009), hlm. 4-5

${ }^{17}$ Imran Ahsan Khan Nyazee, Islamic Law of Business Organization (Corporation), (Pakistan: The International of Islamic Thought, 1998), P. 10 acceptance between partners over something. Thus there are always two parties or more in the formation of a company. The work they do forms the subject matter of the contract because this is the reason they have some together. ${ }^{18}$ What needs to be done to apply shari'ah principle in company, therefore, is to clearly understand the basic legal principles operating within the Islamic forms of business organization developed by the earlier jurists (fuqaha). Once these principles have been identified and their operation fully understood, an effort should be made to apply shari'ah principles to the modern form of partnerships company. ${ }^{19}$

\section{Application of Shari'ah Principles in Company}

In the al-Quran and Sunnah, the source of Islamic law, do not regulate about establishing of the company directly. In general, establishing of company is regulated in figh muamalah of which there is a variety contracts that can be applied within the company. Some scholars assert that the current company established based on law of conventional contract is not Islamic. ${ }^{20}$ Their opinions are quite reasonable because the existence of that company until now has not used the reference of shari' ah principles.

There are several models of the company (business organization) in Indonesia. ${ }^{21} \mathrm{How}^{-}$

${ }^{18} \mathrm{http}: / / \mathrm{www} \cdot \mathrm{khilafah} . \mathrm{com} /$ index.php/thekhilafah/economy/1029-companies-in-islam

${ }^{19}$ Imran Ahsan Khan Nyazee, Islamic Law of Business Organization (Partnerships), (Pakistan: The International of Islamic Thought, 2000), p. 20

${ }^{20}$ In this case, see Taqiyuddin an-Nabhani (2004), Yusuf as-Sabatin (2002), dan Ali Ahmad as-Salus (2006). They argue that this form of limited liability (PT) is not Islamic. So, before looking at the business company, should be seen first is a form of legal entity (limited liability) whether the company qualifies as Islamic (Syirkah Islamiyah) or not. See M.Siddiq al-Jawi, http://hizbut-tahrir.or.id/2007/10/01/jual-beli-sahamdalam-pandangan-islam/, diakses tanggal 7 Oktober 2010

${ }^{21}$ In a book entitled, Hukum Bisnis Untuk Perusahaan, (Jakarta: Prenanda Media, 2005), Abdul R. Saliman dkk mention other forms of company organization includes: Trading Company, Perdata Partnership, Sole proprietorship, Firm Partnership (Fa), Commanditer Partnership (CV), Limited Liability Company (PT). 
ever, all of those companies in Indonesia have not been incorporated under shari'ah contract, so that their existence should be Islamized. The obligation requires that the fundamental reason for Islamizing the company must be the same as that for Islamizing of the modern banking business or of the economic as a whole. ${ }^{22}$ The reason is reflected in the questioned, "Does the modern company violate the basic principles of the shari'ah?" In other words, is the company preventing Muslim from organizing their business activity in accordance with the dictates of the syar'i norm?

As the company is merely an organizing concept, the process of Islamization of the company may ultimately involve a few minor changes. If this is the case, it will a smooth transition from the existing company will yield a new model, an Islamic company. An obvious question that arises here is as to why the concept of company has not been examined so far in the light of shari'ah, if it is so important for Islamic commercial law? A more specific response concerns the defective assumptions made by scholars with respect to research in the area of traditional business law. While most scholars mention the general principles of Islamic law, it is the application of these principles and their relationship with the modern company that is not undertaken efficiently. ${ }^{23}$ To solve this problem, the integration approach is the best option.

Analyzing the structure of modern business company means that we should first verify the nature of the contract that exists between the shareholders and the company. ${ }^{24}$ This step of course can be taken if the company itself has been formed by the owners. ${ }^{25}$ Once the nature of that contract has

\footnotetext{
${ }^{22}$ Ali Muhiy al-Din Raghi, Majallat Majma' al-Figh alIslami, (1992), p.85

${ }^{23}$ Ali Muhiy al-Din Raghi, Majallat, p. 12

${ }^{24}$ Imran Ahsan Khan Nyazee, Islamic Law of Business Organization (Corporation), (Pakistan: The International of Islamic Though, t1998), p. 19

${ }^{25}$ Establishing the company, in the concept of Islam, must rely on syirkah as an underlying contract of the owners. How to apply that syirkah contract in a
}

been analyzed, it should be compared with the contracts available in traditional Islamic law (figh). The analysis of the contract should reveal how distribute rights and obligation, include a liability of parties. After the analysis has been undertaken, confirm that the structure of company has not a conflict with shari'ah principles. If there is a conflict, its company must be reformed.

In general, there are two main types of company in the Indonesian commercial area, namely sole proprietorship and partnerships. ${ }^{26}$ The company, founded and owned by an entrepreneur who has enough capital is called sole proprietorship. ${ }^{27}$ Sole proprietorship appears to dominate the informal sector. Many of these businesses are not officially registered with Indonesian authorities because of thenature and activities of the informal sector. ${ }^{28}$ The establishment of sole proprietorship is very simple so there is no problem when viewed from the aspects of shari'ah law.

Sole proprietorship can be established directly by owner alone. To establish a sole proprietorship does not provide any mix of capital with other parties. Sole proprietorship's capital usually comes from owner, as well as in the distribution of profits and losses. In other words, the legal consequences arising from the establishment of these companies will be borne by the owners themselves. But if the owners of individual company lack capital, they can apply for funding to another party. ${ }^{29}$

The sole proprietorship is the simplest business form under which one can operate a business. The owner of a sole proprietorship

\footnotetext{
company will be explained in the next paragraph.

${ }^{26}$ Burhanuddin S, Hukum Bisnis Syariah, p. 15

${ }^{27}$ Ibid., p. 20

${ }^{28}$ Benny S. Tabalujan, "The New Indonesia Company", Journal Business, Vol. 17, p. 884

${ }^{29} \mathrm{~A}$ person or financial institutions can give financing to sole proprietorship through various Islamic contracts. Parties who give a tijarah financing have a rights to get the compensation of margin, 'ujrah, or profit/ loss sharing, although they are not mean as the owners of company. The syariah approach deferent from a conventional system on which the interest (riba) is applied in financial product.
} 
typically signs contracts in his or her own name, because the sole proprietorship has no separate identity under the law. The sole proprietorship is not a legal entity. It simply refers to a person who owns the business and is personally responsible for its debts alone. This means that the owner has no less liability than if they were acting as an individual instead of as a business. According to shari'ah law, therefore, the establishment of sole proprietorship there is no problem. So, how about the establishment of partnership in which is more complicated?

The company called a partnership when it was founded by several entrepreneurs who engage in the agreement. The establishment background of a partnerships company is due to a production process that could not be run individually but must involve many parties who either incorporated as a company owner, a workers, shareholders, and so on. The relationship between owners of company and company with the workers, are always bound by a treaty according to the contract used. In addition to internal relationship, the company also maintains relationships with external business partners such as by consumers and investors. The forms of those relationships are always based on mutual agreement that is established by relevant contract. The involvement of all parties in a company needs to obtain strict legal supervision. This is done in order to guarantee the validity of the shari'ah law during the management process is run, due to the complexity of relationships in the company. ${ }^{30}$

Unlike sole proprietorship, the partnership can be established by the some entrepreneurs used syirkah contract. In the literal sense, the word syirkah is used in the meaning ikhtilât. Ibn al-Humam describes ikhtilat is the attribute of the property that is found a mixed or mingled state, which is mixing of the shares so that one of them cannot be distinguished from another. ${ }^{31}$

\footnotetext{
${ }^{30}$ Burhanuddin S, Hukum Bisnis Syariah, p. 19

${ }^{31} \mathrm{Ibnu}$ al-Humam, Fath al-Qadir ala al-Hidayah Sharh
}

Syirkah is an agreement between two or more persons who agree to run a business aimed to obtain profits. ${ }^{32}$ The legitimacy of the syirkah contract is established based on the Quran, ${ }^{33}$ the Sunnah of the Prophet Muhammad ${ }^{34}$ and the consensus of Muslim jurists. With syirkah contract, allow employers to work together through equity participation and each willing to profit and loss sharing for doing business. Equity participation in syirkah could be realized through the form of money or skills, as well as a combination of both. In this case, the entrepreneurs who first time bind themselves by syirkah contract can be incorporated as a company owner.

\section{The Contract of Company Establishment}

To establish partnership, an entrepreneur needs the cooperation with the other parties concerned. The cooperation to establish partnership is always marked by a capital sharing that its form may be money (al-mal) and work (al-a'mal) according to the ability of each party..$^{35}$ The capital and assets of the partnership are always jointly by partners in their own name. The contract of amânah (trust) requires that the capital or property of the partnership be held in trust by one partner on behalf of the other partners. ${ }^{36}$ To determine the type of syirkah that will be used when setting up a business partnership through the steps that need to be considered are as follow:

1. Be sure whether each participant of

Bidayat al-Mubtadî, (Kairo: Mustafa al-Babi al-Halabi, t.t.), p. 6

${ }^{32}$ Taqiyuddin An-Nabhani, An-Nizham al-Iqtishadi fi Al-Islam, cet. ke-4, (Beirut: Darul Ummah, 2004), hlm. 153

33"...but if more than two, they share in a third..." (QS.Al-Nisa'[4]:12); "Verily many are the partners (in business) who wrong each other except those who believe and work deeds of righteousness and how few of them...." (Al-Sad[38]: 24)

${ }^{34}$ The Prophet SAW said: "Allah says: I am the third (partner) of the two partners as long as they do not betray each other. When one of them betrays the other, I depart from them". (HR. Abu Dawud)

${ }^{35}$ Burhanuddin S, Hukum Bisnis Syariah, p. 20

${ }^{36}$ Al-Marghinani, Kitab al-Hidayah Sharh Bidayah al-Muhtadi, dalam Imran Ahsan Khan Nyazee. Islamic Law of Business Organization (Corporation). (Pakistan: The International of Islamic Thought, 1998), P. 31-33 
partnership company directly involved running the company or not. If the all involved running the company directly, the contract is used musyarakah. If the musyarakah contract is used for establishing a partnership company, the capitals included each party are as follows: (a) If the capital invested by each parties of the same amount of money (Rp. X and Rp. X), the contract used is syirkah mufawadhah; (b) If the capital invested by each parties of the different amount of money (Rp. X and Rp. Y), the contract used is syirkah 'inan; (c) If the capital invested by each party in the form of work (al-a'mal), the contract that is used is syirkah 'abdan also called syirkah $a^{\prime}$ mal; and (d) If one party invests capital in the form of money while the other form of reputation performance, then the contract that is used is there syirkah wujuh. ${ }^{37}$

2. Then if the participant who runs the company only in the form of work (mudharib) while the other party that includes capital assets (shahib al-mal) does not participate in running the company, so the contract used is mudharabah. In this case we need to understand, although mudharib only includes a work (management), but his position remains as an owner of the company. It is said that, because mudharib doses not get benefit from salary ('ujrah) but from profit and loss sharing with a lager authority and a larger share of capital. ${ }^{38}$ While the remuneration (salary) only applies to employees working in the company through ijarah contract.

Small-scale company can be established by syirkah contract of which each syirkah usually

\footnotetext{
${ }^{37}$ For comparison, see Adiwarman A. Karim, Bank Islam: Analisis Fiqih dan Keuangan, (Jakarta: Rajawali Pers, 2004), p. 76

${ }^{38}$ For example, although the bank as a financial institution, its existence can be enabled as mudharib to manage capital deposited by customers. Even production company can issue mudharabah sukuk to obtain additional capital from investors. A company that will issue mudharabah sukuk required through screening process to prevent conflict with the syariah principles. Burhanuddin S, Pasar Modal Syariah (Tinjauan Hukum), (Yogyakarta: UII Press, 2008), p.
}

can be used alone separately. Meanwhile, to establish large-scale partnership company required the existence of various contracts until at a certain level of complexity from which each contracts can be combined. ${ }^{39}$ According to Nabhani, therefore, every contract which may be applied according to shari'ah view, it is also can be combined with other contracts on condition that the implementation is done separately. ${ }^{40}$ After agreement of forming a partnership reached, entrepreneurs should appoint employees as workers. The simple question is how to recruit the employees in the view of shari'ah?

\section{Recruitment of Employees}

A company needs to perform the contract every time will appoint the employees. The company that has raised employee must provide wages in accordance with the work performed. If the company gives salary in the form of wages ('ujrah), then the contract is commonly used is ijarah. In this case, company is like buying benefit from the workers until a certain period of which the salary can be given every month. Related to the distributing of employee salaries, ijarah contract is more relevant than any other contracts. There is a legal base to justify the application of ijarah contract in recruitment, namely:



This hadith gives an understanding of how we do ijarah contract that concerned with clarity of the nominal wage ("ujrah) which will be paid. Determining the amount of wage after at the time of agreement (ijab qabul) is a matter of principle in ijarah contract. ${ }^{41}$

$$
\text { اعطوا الاجير اجره }
$$

\footnotetext{
${ }^{39}$ Burhanuddin S, Hukum Bisnis Syariah, p. 21

${ }^{40}$ Taqiyuddin An-Nabhani, An-Nizham al-Iqtishadi fi Al-Islam, p. 156

${ }^{41}$ Burhanuddin S, Figh Muamalah: Dasar-Dasar Transaksi dalam Ekonomi dan Bisnis, (Yogyakarta: Ijtihad Ilmu, 2010), p. 111
} 


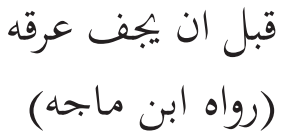

Viewed from the responsibility of the employees who will get a wage, the ijarah contract generally can be divided into two: (1) ijarah toward individual works (ijarah 'ala al-amal al-fardiyah); (2) ijarah toward the collective works (ijarah 'ala al-amal almusytarikah). Thus, associations of employees who perform the collective work called 'ajir al-musytarikah. ${ }^{42}$

\section{Legal Entity}

The term legal entity in fiqh called shakhsîyah i'tibârîyah, as opposed to humans in real terms (shakhsîyah haqîqîyah). ${ }^{43}$ In a modern company, legal entity usually will act as a subject of law who is authorized to perform the rights and obligations of the business. Legal entity said to be the subject of law (mahkūm 'alayh) because it consists of a collection of people who perform legal acts (tasharruf). ${ }^{44}$ Although human action on behalf of a legal entity, but remain vertical accountability is returned to each person..$^{45}$ People who work for an institution (legal entity) are legalized, in this case, the existence of them only as the representative (wakîl) of the institution. Therefore, implementation of legal entity within Islamic company is not a problem.

Isa Abduh, in his book al-'Uqūd alSyari'îyah al-Hâkimah, had the following to say: "It is agreed upon that fictitious personality (legal entity) does not find support from Islamic heritage. Despite this, the texts of Arabs as well as Muslims convey the idea that it can be established." 46 Abdu Rahim in his book, Principles of Islamic Jurisprudence, said:

${ }^{42}$ Ibid., p. 113

${ }^{43}$ Muhammad Hasbi Ash-Shiddiqy, Pengantar Fiqh Muamalah, (Semarang: Pustaka Rizki Putra, 2001), p. 197

${ }^{44}$ Burhanuddin S, Fiqh Muamalah: Dasar-Dasar Transaksi dalam Ekonomi dan Bisnis, p. 41

${ }^{45}$ "Every soul is responsible for what has done" (QS.AlMuddatsir[74]38).

${ }^{46}$ Isa 'Abduh, Al-'Uqūd al-Syari'îyah al-Hâkimah, (Kairo: Dal al-I'tisam, 1977), p. 25
"It may be doubted whether the earlier jurists would recognize an artificial or juristic person. The community or state.....but later jurists seem inclined to recognize an artificial person." 47 Abdul Qadir Awdah states that Islamic shari'ah, from the first day of its existence, has recognized juristic person (legal entity). ${ }^{48}$ His opinion was rapidly accepted by most modern scholars, beginning with Mustafa alZarqa. ${ }^{49}$

\section{Reconstruction of Liability Concept}

All types of profit in Islamic law are justified on the basis of liability (damân). In fact, the rule that links liability with ownership operates not only in partnership law, but in the entire Islamic law of contract. The principle of liability is well known and is expressed in a rule of fiqh as al-kharâj bi aldamân..$^{50}$ In the company law, with reference to rule of fiqh, we divide the concept of damân in two parts, (1) limited liability and (2) unlimited liability, each of which can be applied to the company separately. This way is taken as an alternative to the acceptance of limited liability concept absolutely of which can violate Islamic principles regarding debt (al-dayn) responsibility. ${ }^{51}$

Unlimited liability can be applied not only on sole proprietorship but also partnership company. In the concept of company, sole proprietorship has unlimited liability is

${ }^{47} \mathrm{Abdu}$ Rahim, Principles of Islamic Jurisprudence, (Madras, n.p), p. 318; Imran Ahsan Khan Nyazee. Islamic Law of Business Organization (Corporation), p. 89

${ }^{48}$ Abdul Qadir Awdah, Al-Tashrî al-Jinâî al-Islamî, (Beirut: al-Muassasat ar-Risalah,1992), p. 393

"49"When we referred to the original texts and sources of the Shari'ah, we found in it legal provisions which in substance propounds the concept of juristic person and its legal status. And, also, we found the legal provisions which personify the juristic person (legal entity) with all its principles and characteristics which are attributed to it by the latest (modern) law." See Musthafa Ahmad al-Zarqa , Al-Madkhal al-Fighî al-'Aam, (Beirut: Darul Fikri, t.t.), I:253

${ }^{50}$ Burhanuddin S, Hukum Kontrak Syariah, (Yogyakarta: BPFE UGM, 2009), p. 43

${ }^{51}$ The liability of partner for the debts of partnership (syirkah) owner is unlimited, and Islamic law does not acknowledge the concept of limited liability as we know it in modern law for corporations and limited liability company. Imran Ahsan Khan Nyazee, Islamic Law of Business Organization (Corporation), p. 67 
a natural. Then, how about a partnership company that owned by a lot of people? To answer that question, first we must distinguish between owners of company and investors. The owner of company is the person who established the company or person who buys majority shares of the company until a certain amount, for example at least $60 \%$ of total shares. In the Islamic concept, the owners of company have unlimited liability toward the debt when the company become insolvent. This means that the creditors have access to the personal wealth of all company's owners (syârik) according to ratio of capital which included each party.

If the owners have $60 \%$ of the company's assets, the rest asset $(40 \%)$ can be sold to the public (investors) through the issuance of commercial papers (sukuk). ${ }^{52}$ Theissuing sukuk can be done when the capital is insufficient for financing a company. In running the business, there are three possibilities that faced the company, namely profit/ (+) return), loss/ (-) return, or breakeven/ (0) return..$^{53}$ The profit distribution ratio can be decided according to what is agreed in the contract i.e. 50/50, 40/60 etc whilst the loss is distributed relative to the amount each partner invests in the business. This provision refers to the rule

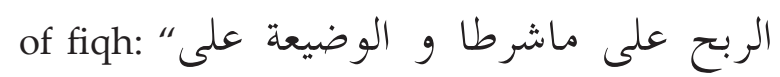

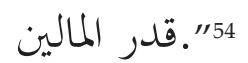

The owners of company will not be limited to the amount put in, thus there is no limited liability for them. According to Hans Kelsen, the of limited liability arises from the concept of legal entity. "قدر المالين , for the owner of company, is not only interpreted as a capital of partnership (syirkah) but also including personal wealth.

\footnotetext{
${ }^{52}$ Term Sukūk (صكوك), plural of Sakk (صك) is the arabic name for financial certificates. Burhanuddin S, Hukum Surat Berharga Syriah Negara dan Pengaturannya, (Jakarta: Rajawali Pers, 2011), p. 6

${ }^{53}$ Adiwarman A. Karim,

${ }^{54}$ The profit is divided according to the consensus, while the loss is divided based on the capital of each parties.

${ }^{55}$ Hans Kelsen, General Theory of Law and State, (Tp: Trans Wedberg, 1945), p. 92;
}

In a state of bankruptcy, however, all owners of company have unlimited liability for company's debt based on capital ratio that is included. In Islam, those who fail to pay back their debts are given the sternest of warnings. ${ }^{56}$ So if one party will divest the company's debt, the he must be approved by the other party. Approval of other partners is a form of agreement (ijab qabul) in the syirkah contract.

Investors are people who include their capital to the public company through a system of profit and loss sharing. Unlike the owner of company, although investors (shareholders) were sharing profit with the partnership company, their liability were limited to extent of their shares. This means that the creditors do not have access to the personal wealth of the investors, except wealth that has not been invested in the company. In this case, the position of the investors are identical to that of a rabb al-mâl (owner of capital) formed by shari'ah contract with the lowest priority in claim. The number of investors in a modern company is too many, hence the transfer of shares to other investors can be done without the agreement of company. Anyone who bring the shares of company have the right to get profit sharing. It is for the reason that in the new concept there is unlimited liability for the owners of company, and the term "limited liability" merely applies to the investors by profit and loss sharing.

\section{CONCLUSION}

Shari'ah principles could be applied to establish the company. In establishing the company, the function of its principles is as an underlying of contract. If the shari'ah principles are applied, however, there are some structures of the company that need to be reconstructed, and one of the most relevance is the concept of partnership company in which the shari'ah principles have not been applied. Ideally, a basic

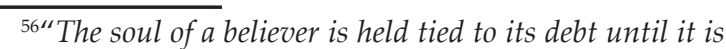
paid on his behalf." (HR.Ahmad, Tirmidhî, Ibnu Mâjah) 
contract of the partnership is the syirkah in which there is kind of types, i.e. mufâwadah, 'inân, wujūh, and abdân, as well as mudârabah. Even, under ijarah contract, the owners of company may appoint an employee with the system of wage ('ujrah). Unlike the investors

\section{DAFTAR PUSTAKA}

'Abduh,Isa. Al-'Uqūdal-Syari'îyahal-Hâkimah. Kairo: Dal al-I'tisam, 1977

A-Humam, Ibnu. Fath al-Qadir ala al-Hidayah Sharh Bidayatal-Mubtadî. Kairo: Mustafa al-Babi al-Halabi, t.th

Al-Jawi, M.Siddiq, http://hizbut-tahrir. or.id/2007/10/01/jual-beli-sahamdalam-pandangan-islam/, diakses tanggal 7 Oktober 2010

An-Nabhani, Taqiyuddin. An-Nizham al-Iqtishadi fi Al-Islam. cet. ke-4. Beirut: Darul Ummah, 2004

Al-Marghinani. Kitab al-Hidayah Sharh Bidayah al-Muhtadi, dalam Imran Ahsan Khan Nyazee. Islamic Law of Business Organization (Corporation). Pakistan: The International of Islamic Thought, 1998

Al-Zarqa, Musthafa Ahmad. Al-Madkhal al-Fiqhî al-'Aam. Beirut: Darul Fikri, t.th

Ash-Shiddiqy, Muhammad Hasbi. Pengantar Fiqh Muamalah. Semarang: Pustaka Rizki Putra, 2001

Awdah, Abdul Qadir. Al-Tashrîal-Jinâîal-Islamî. Beirut: al-Muassasat ar-Risalah, 1992

.Hukum Surat Berharga Syriah Negara dan Pengaturannya. Jakarta: Rajawali Pers, 2011

Indonesia Constitution of 1945 in Article II of Transitory Provisions

Indonesia Commercial Code [KUHD], cet ke-4, Bandung: Citra Umbara (shareholders), all owners of company have unlimited liability for company's debt based on capital ratio that is included. This means that the creditors have access not only to capital that has been invested but also the private wealth.

Karim, Adiwarman A. Bank Islam: Analisis Fiqih dan Keuangan, Jakarta: Rajawali Pers, 2004

Kelsen, Hans. General Theory of Law and State. Trans Wedberg, 1945

Muhammad, Abdulkadir. Pengantar Hukum Perusahaan di Indonesia. Bandung: Citra Aditia Abadi, 1995

Nyazee, Imran Ahsan Khan. Islamic Law of Business Organization (Corporation), Pakistan: The International of Islamic Thought, 1998

Nyazee, Imran Ahsan Khan. Islamic Law of Business Organization (Partnerships), Pakistan: The International of Islamic Thought, 2000

S., Burhanuddin. Hukum Bisnis Shari'ah, cet ke-1. Yogyakarta: UII Press, 2010

S., Burhanuddin. Pasar Modal Shari'ah: Tinjauan Hukum. Yogyakarta: UII Press, 2009

S., Burhanuddin. Hukum Surat Berharga Syriah Negara dan Pengaturannya. Jakarta: Rajawali Pers, 2011

Saliman, Abdul R. Hukum Bisnis Untuk Perusahaan. Jakarta: Prenanda Media, 2005

Undang-Undang No.3 Tahun 1982 tentang Wajib Daftar Perusahaan. [Law No. 3 of 1982 concerning The Compulsory Enterprise Registration] 